\title{
Sistem Informasi Akuntansi pada Pondok Pesantren Ahmad Dahlan Berbasis Dekstop
}

\author{
Aprillia Dwi Sartika \\ Fakultas Teknik, Universitas Merdeka Madiun, Jl. Serayu No. 79, Madiun, 63133 \\ E-mail: prilapriillia@gmail.com
}

\begin{abstract}
Financial management systems in Islamic boarding schools Ahmad Dahlan have used in the use of computers, namely by noting a financial report in and out in Microsoft Excel. But the use of devices the computers are not optimal. Due to lack of use, Microsoft excel cause to the emergence of a new problem, among others file that is stored too long susceptible to broken or corrupt. Hence the writer provides solutions by building an information system that might increase the ease of, the accuracy of and security. In addition, this accounting information system can make maximum use of computers in the management of financial data and does not require the time and place of plenty for its final resting. The methodology used is in the design of this is a waterfall with modeling UML ( The unified modeling language) as modeling graphic. There are several stages in the development of which is executed is system design, analysis, the design of a model, implementation, testing, and maintenance or care. The accounting information system is able to give a solution to the existing problems with reference to the design process that they were previously, hopefully with this application can help in processing financial data in Ahmad Dahlan Islamic boarding schools.
\end{abstract}

Keywords—: Accounting Information Systems; Financial Reports; Waterfall; Dekstop; Mysql.

\section{PENDAhULUAN}

Pondok Pesantren merupakan salah satu institusi pendidikan yang memiliki peran strategis di dalam menyiapkan calon pemimpin bangsa yang akan datang. Pondok Pesantren Ahmad Dahlan ini lahir ditengah-tengah masyarakat, khususnya masyarakat islam. Didirikannya pondok pesantren bertujuan untuk memberikan pembelajaran mengenai ilmu agama kepada para santrinya supaya bisa menjadi bekal untuk hidup baik di dunia maupun di akhirat. Tidak sedikit pondok pesantren yang mencoba untuk menyesuaikan diri akan suatu perubahan, namun ada juga pondok pesantren yang menutup diri dari pengaruh perkembangan teknologi saat ini (Alparisi \& Bunyamin, 2015).

Pada Pondok Pesantren Ahmad Dahlan ini terjadi banyak proses administrasi didalamnya. Diantaranya seperti pendaftaran santri baru, daftar ulang santri dan wakaf sedekah serta usaha pondok. Saat ini proses pengelolaan keuangan tersebut sudah memanfaatkan perangkat komputer, yaitu dengan mencatat laporan keuangan yang masuk dan keluar pada Microsoft Excel. Namun pemanfaatan perangkat komputer tersebut dirasa kurang maksimal.

Dengan metode pencatatan menggunakan Microsoft Excel tersebut, menyebabkan timbulnya beberapa permasalahan antara lain yaitu file yang disimpan terlalu lama rentan rusak atau corrupt. Selain permasalahan tersebut terdapat kelemahan yaitu tidak dapat membuat laporan secara otomatis karena rumus-rumus hitungnya harus dibuat terlebih dahulu sehingga waktu yang digunakan tidak efektif.

Dari penelitian sebelumnya aplikasi sistem informasi akuntansi telah dikembangkan oleh (Andreas dkk, 2004) aplikasi ini berbasis dekstop dengan bahasa pemrograman Pascal atau Borland Delphi 7.0 sebagai compiler-nya dan MySQL sebagai database-nya. Aplikasi yang dikembangkan tersebut mampu membantu proses pencatatan dengan melakukan otomatisasi penjurnalan dan posting serta membantu mempercepat proses pembuatan laporan laba rugi perusahaan

Oleh karena itu, dengan adanya sistem informasi akuntansi diharapkan dapat meningkatkan kemudahan, ketepatan, dan keamanan laporan keuangan tersebut. Sehingga sistem ini diharapkan dapat mempermudah dalam pencatatan laporan keuangan, mengingat pentingnya laporan keuangan bagi suatu lembaga yang digunakan untuk menggambarkan kinerja lembaga tersebut.

Metode penelitian pada tugas akhir ini dimulai dengan pengumpulan data-data pendukung, identifikasi masalah, analisis kebutuhan sistem, analisa kebutuhan user, membuat desain sistem, membangun perangkat lunak, dan dilanjutkan dengan tahap pengujian perangkat lunak. Hasil dari pengerjaan tugas akhir ini adalah perangkat lunak untuk mengelola laporan keuangan di Pondok Pesantren Ahmad Dahlan.

\section{METODE PENELITIAN}

Objek Penelitian ini adalah lembaga pendidikan Pondok Pesantren Ahmad Dahlan yang beralamatkan di Jl. Bismo Mojorejo, Caruban, Kab. Madiun. Dalam penelitian ini, penulis menganalisis masalah dengan menggunakan data laporan keuangan. Setelah itu penulis menetapkan perancangan dan pengembangan aplikasi ini menggunakan metode pengembangan Waterfall. Metode Waterfall memerlukan pendekatan yang sistematis dan sekuensial dalam pengembangan sistem perangkat lunaknya yang mulai pada tinggat dan kemajuan sistem pada seluruh analisis, desain, kode, pengujian, dan pemeliharaan (Mariani dkk, 2010). Berikut ini adalah gambaran langkah langkah yang digunakan dalam penelitian ini ditampilkan pada gambar 1. 


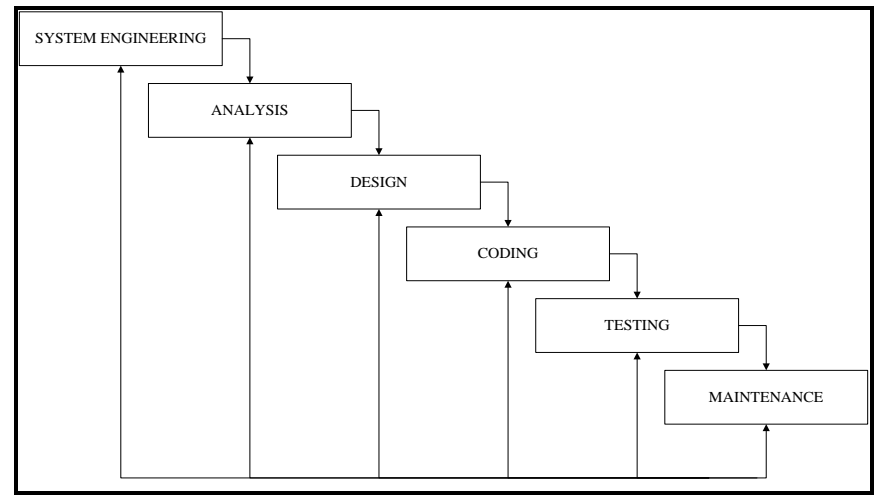

Gambar 1. Tahapan Metode Waterfall

1. Perancangan Sistem (Sistem Engineering)

Perancangan sistem sangat diperlukan karena perangkat lunak biasanya merupakan bagian dari suatu sitem yang lebih besar. Pembuatan sebuah perangkat lunak dapat dimulai dengan melihat dan mencari apa yang dibutuhkan oleh sistem.

2. Analisis Kebutuhan Perangkat Lunak (Analysis)

Merupakan proses pengumpulan kebutuhan perangkat lunak. Untuk memahami dasar dari program yang akan dibuat seseorang analisis harus mengetahui ruang lingkup informasi, fungsi-fungsi yang dibutuhkan dan perancangan antar muka perangkat lunak tersebut.

3. Perancangan (Design)

Merupakan proses yang memfokuskan pada empat bagian penting, yaitu struktur data, arsitektur perangkat lunak, detai prosedur, dan karakteristik antar muka pemakai.

4. Pengkodean (Coding)

Merupakan tahap penulisan bahasa program atauimplementasi dari tahapan design agar perangkat lunak tersebut dapat dijalankan oleh mesin.

5. Pengujian (Testing)

Merupakan proses pengujian kode program yang telah dibuat dengan memfokuskan pada bagian dalam perangkat lunak.

6. Pemeliharaan (Maintenance)

Proses perawatan atau pemeliharaan perangkat lunak oleh pemakai. Perubahan akan dilakukan jika terdapat kesalahan, oleh karena itu perangkat lunak harus disesuaikan lagi untuk menampung perubahan kebutuhan yang diinginkan oleh pemakai.

\section{III.HASIL DAN PEMBAHASAN}

Tahapan pertama dalam perancangan sistem adalah dengan menggambarkan Entity Relationship Diagram (ERD). ERD akan menghasilkan gambaran data apa saja yang akan diperlukan dan bagaimana data satu berhubungan dengan yang lainnya. Adapun ERD dari Sistem dapat ditampilkan pada Gambar 2.

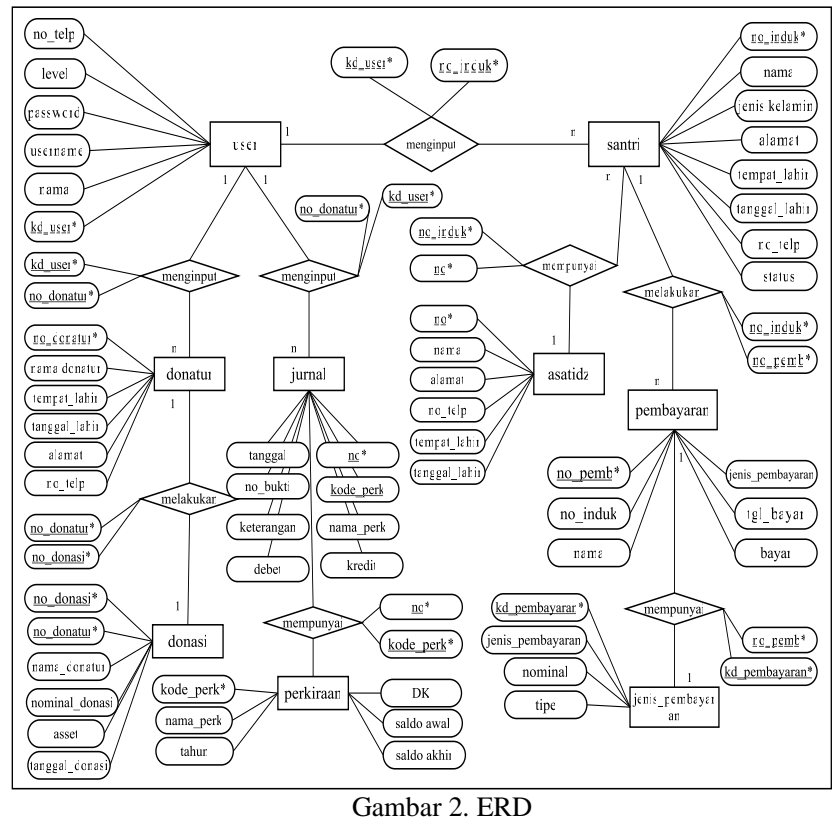


Pada gambar 2 ERD, dapat disimpulkan bahwa user yang memiliki hak akses dapat mengelola berapa data seperti mengelola data santri, mengelola data user, mengelola data asatidz atau pengajar, mengelola data donatur, mengelola data jenis pembayaran, mengelola data perkiraan, mengelola data donasi, mengelola data pembayaran, mengelola data jurnal.

Sementara itu prancangan pada database dapat diumpamakan sebagai sebuah tempat penyimpanan data yang terstruktur agar dapat diakses dengan cepat dan mudah. Dalam perancangan sistem informasi akuntansi ini dibuat 10 tabel dalam database. Tabel - tabel tersebut adalah tabel santri, tabel user, tabel asatidz, tabel donatur, tabel jenis pembayaran, tabel perkiraan, tabel donasi, tabel pembayaran dan tabel jurnal. Dalam pembuatan database dan tabel-tabel nya penulis menggunakan database $M y S Q L$

Unified Modelling Language (UML) merupakan bahasa pemodelan grafis yang digunakan untuk menspesifikasikan memvisualisasikan, membangun dan mendokumentasikan seluruh proses yang ada dalam perangkat lunak (Mustakim, 2013). Pemodelan dengan UML bertujuan untuk mempermudah mengidentifikasi bagian-bagian yang termasuk dalam lingkup sistem. UML memiliki 3 jenis diagram yang dapat digunakan untuk melakukan pemodelan yaitu :

1. Use Case Diagram digunakan untuk menggambarkan kebutuhan fungsional sistem tanpa menampilkan struktural sistem.

2. Sequence Diagram digunakan untuk menggambarkan event yang dilakukan oleh aktor eksternal yang dapat dilihat dalam satu use case.

3. Activity Diagram digunakan untuk memperlihatkan alur dari satu aktivitas ke aktivitas lainnya.

Diagram use case adalah diagram yang menunjukan segala aktivitas dan proses menjalankan program aplikasi. Dalam diagram use case ini dijelaskan proses yang terkait dengan actor (user) dan sistem. Interaksi tersebut dapat digambarkan dengan usecase diagram (Mustakim, 2013). Dalam prosesnya akan dijelaskan rincian dari setiap use case yang ada seperti yang ditunjukkan dalam gambar 3 dibawah ini.

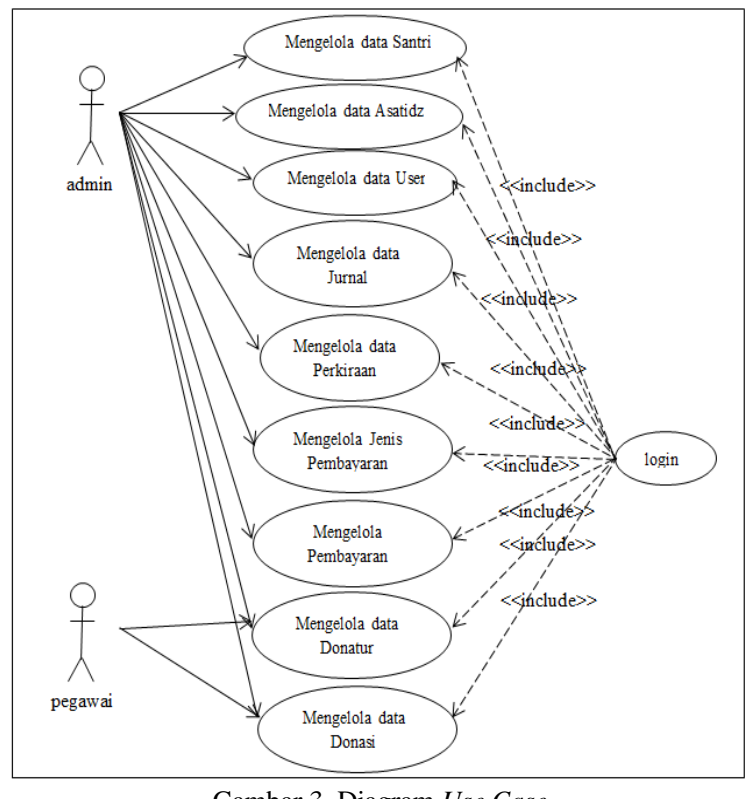

Gambar 3. Diagram Use Case

Pada gambar 3 diatas, terlihat bahwa user setelah login ke sistem dengan menginputkan username dan password, dapat melakukan beberapa aktivitas untu mengelola sistem seperti dapat mengelola data user, santri, asatidz, data jenis pembayaran, data pembayaran, data donatur dan donasi, data jurnal dan lain-lain dengan cara menginput data, mengubah data dan menghapus data.

Apabila user/pemakai ingin menjalankan sistem informasi maka user diwajibkan untuk melakukan Login terlebih dahulu. Berikut adalah implementasi dari Form Login. Tampilan Form Login dapat dilihat pada Gambar 4. 
Website : http://pilar.unmermadiun.ac.id/index.php/pilarteknologi

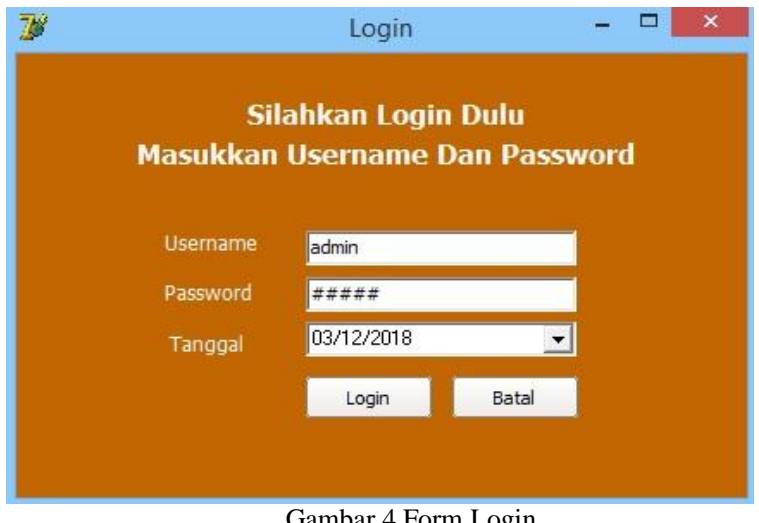

Setelah melakukan login, maka user akan dibawa pada form menu utama. Berikut adalah implementasi dari Form Menu Utama. Tampilan Form Menu Utama dapat dilihat pada Gambar 5.

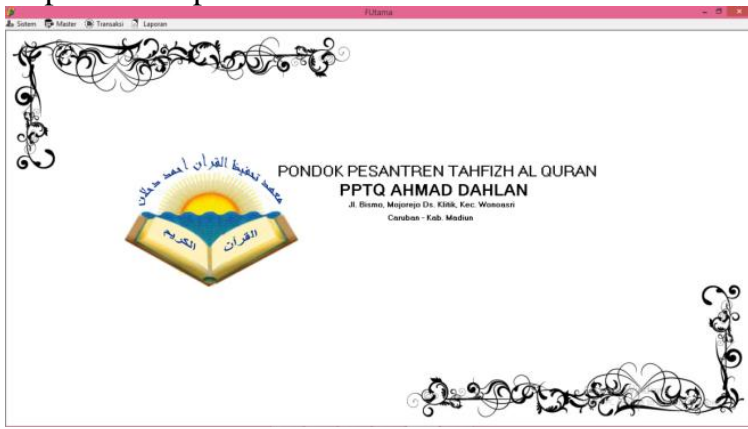

Gambar 5 Form Menu Utama

Selanjutnya user dapat melakukan pengolahan data santri seperti input data, update data dan hapus data santri. Tampilan form data santri dapat dilihat pada Gambar 6 dibawah ini.

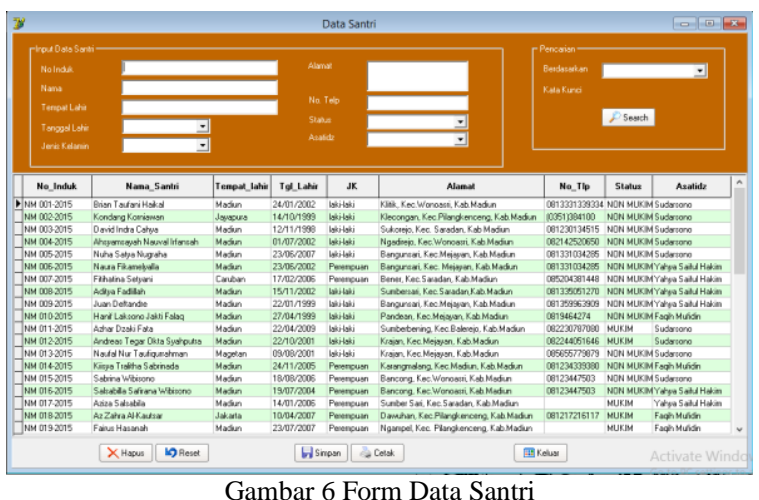

User dapat mengolah data asatidz pada form asatidz untuk menginput, mengedit, menghapus asatidz atau pengajar. Form data asatidz dapat dilihat pada gambar 7 dibawah ini.

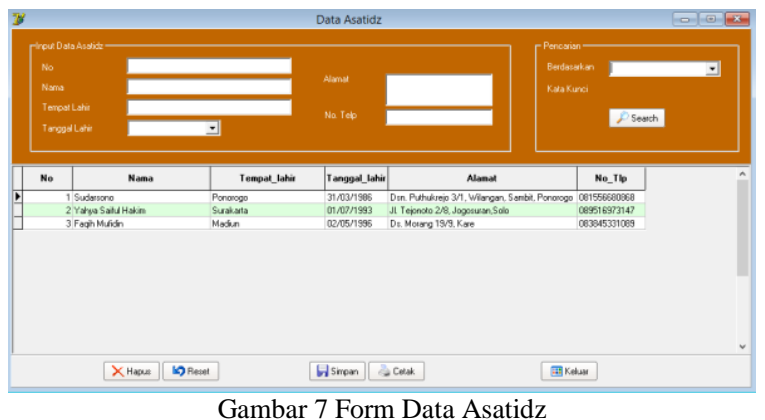


User dapat mengolah data user pada form user untuk menginput, mengedit, menghapus data user.Form data user dapat dilihat pada gambar 8 dibawah ini.

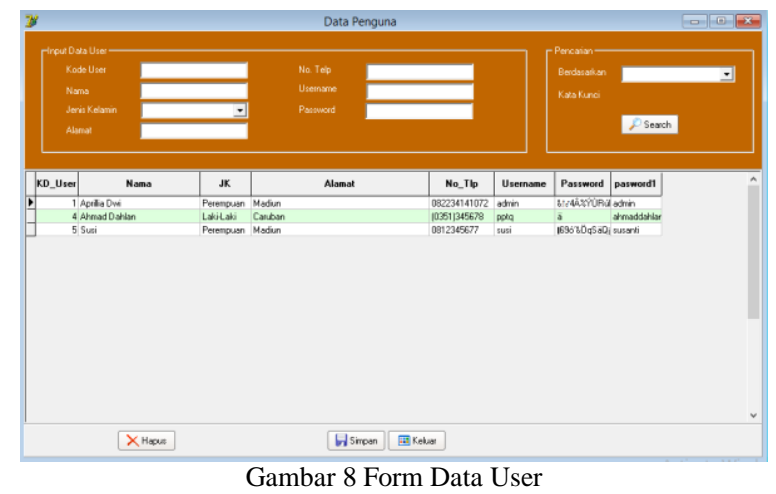

Halaman atau Form jenis pembayaran ini digunakan untuk menginputkan, mengedit, menghapus transaksi pembayaran santri. Berikut ini tampilan halaman atau form pembayaran santri dapat dilihat pada gambar 9 dibawah ini.

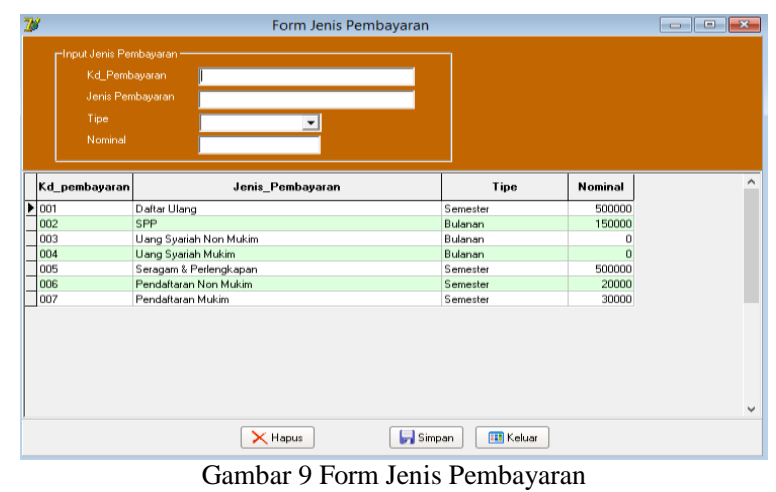

Form donatur disediakan untuk menginputkan data donatur yang terlibat dalam pembayaran donasi. Selain itu pada form donatur ini user dapat melakukan edit dan hapus data user. Form data donatur dapat dilihat pada gambar 10 dibawah ini.

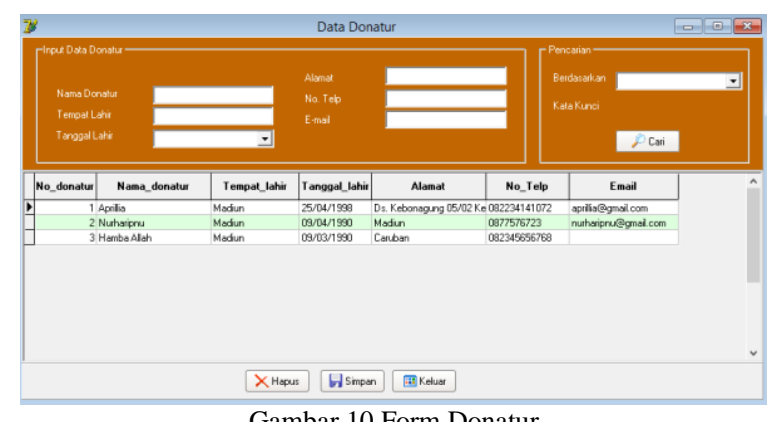

Pada Form transaksi ini, user dapat menginputkan, mengedit, menghapus data pembayaran, dan mencetak laporan pembayaran. Form transaksi dapat dilihat pada gambar 11 dibawah ini.

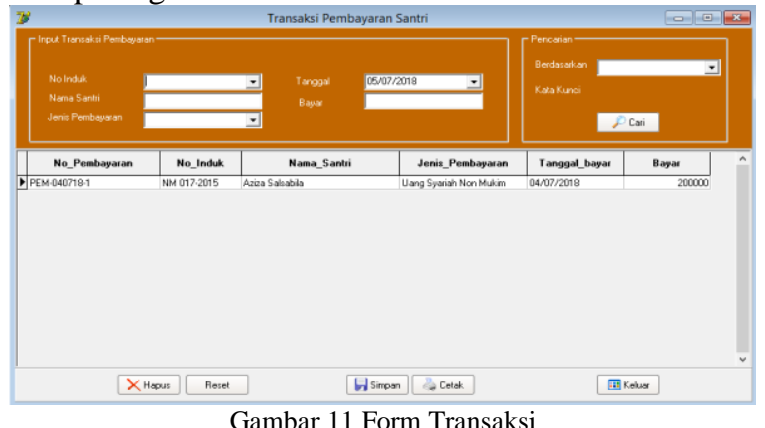


User dapat mengeloah data donasi pada Form donasi. Form donasi disediakan untuk menginputkan, mengedit, menambah, mencetak data donasi. Form data donasi dapat dilihat pada gambar 12 dibawah ini.

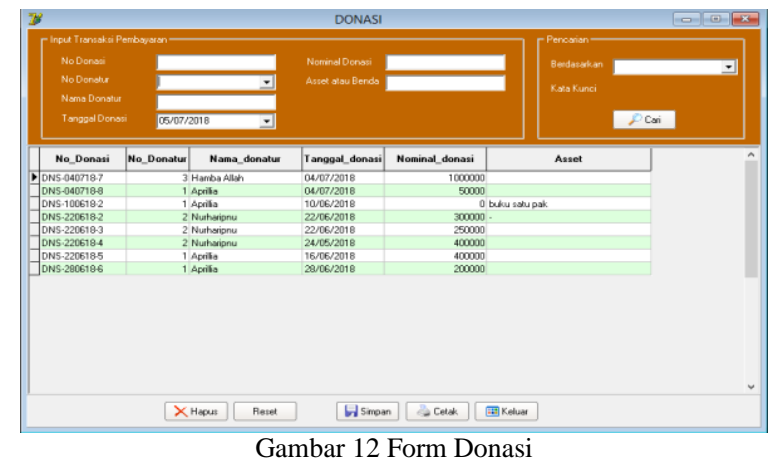

Form perkiraan disediakan untuk menginputkan data perkiraan atau kode akuntan. Data perkiraan ini sangat diperlukan untuk menginputkan data jurnal nantinya. Form data perkiraan dapat dilihat pada gambar 13 dibawah ini.

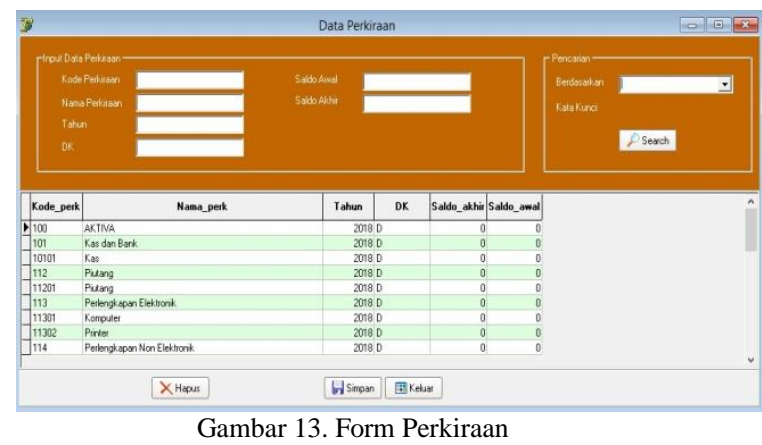

Form jurnal disediakan untuk menginputkan data transaksi keuangan yang terjadi pada instansi yang bersangkutan. Pada form jurnal ini akan diolah lebih lanjut untuk menghasilkan beberapa laporan seperti, laporan jurnal, laporan buku besar, laporan neraca, laporan laba rugi. Form jurnal dapat dilihat pada gambar 14 dibawah ini.

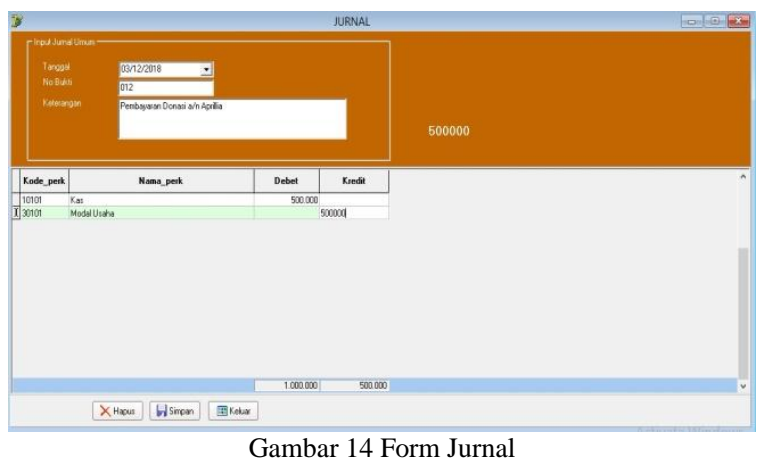

Setelah dilakukan implementasi, dilakukan pengujian sistem menggunakan Blackbox dan hasilnya dapat dilihat pada Tabel 1.

Tabel 1. Pengujian Menggunakan BlackBox.

\begin{tabular}{llll}
\hline No & Skenario Pengujian & Tes & Hasil \\
\hline 1 & Menginputkan data & Username:admin & Sesuai Harapan \\
& $\begin{array}{l}\text { username dan password } \\
\text { dengan benar, lalu klik } \\
\text { tombol Login }\end{array}$ & Password & \\
2 & $\begin{array}{l}\text { Menginputkan form data } \\
\text { santri edit data, serta hapus } \\
\text { data sesuai dengan }\end{array}$ & $\begin{array}{l}\text { Tambah, edit, } \\
\text { hapus data nilai } \\
\text { keinginan }\end{array}$ & Sesuai Harapan \\
& $\begin{array}{l}\text { Menginputkan form data } \\
\text { user edit data, serta hapus } \\
\text { data sesuai dengan }\end{array}$ & Tambah, edit, & Sesuai Harapan \\
keinginan & & & \\
& & &
\end{tabular}


Website : http://pilar.unmermadiun.ac.id/index.php/pilarteknologi

\begin{tabular}{|c|c|c|c|}
\hline 4 & $\begin{array}{l}\text { Menginputkan form data } \\
\text { asatidz, tambah data } \\
\text { alternatif, edit serta hapus } \\
\text { data alternatif sesuai } \\
\text { dengan keinginan }\end{array}$ & $\begin{array}{l}\text { Tambah, edit, } \\
\text { hapus data } \\
\text { alternatif }\end{array}$ & Sesuai Harapan \\
\hline 5 & $\begin{array}{l}\text { Menginputkan form data } \\
\text { donatur edit data, serta } \\
\text { hapus data sesuai dengan } \\
\text { keinginan }\end{array}$ & $\begin{array}{l}\text { Tambah, edit, } \\
\text { hapus data } \\
\text { alternatif }\end{array}$ & Sesuai Harapan \\
\hline 6 & $\begin{array}{l}\text { Menginputkan form data } \\
\text { jeni pembayaran edit data, } \\
\text { serta hapus data sesuai } \\
\text { dengan keinginan }\end{array}$ & $\begin{array}{l}\text { Tambah, edit, } \\
\text { hapus data } \\
\text { alternatif }\end{array}$ & Sesuai Harapan \\
\hline 7 & $\begin{array}{l}\text { Menginputkan form data } \\
\text { perkiraan edit data, serta } \\
\text { hapus data sesuai dengan } \\
\text { keinginan }\end{array}$ & $\begin{array}{l}\text { Tambah, edit, } \\
\text { hapus data } \\
\text { alternatif }\end{array}$ & Sesuai Harapan \\
\hline 8 & $\begin{array}{l}\text { Menginputkan form data } \\
\text { donasi edit data, serta } \\
\text { hapus data sesuai dengan } \\
\text { keinginan }\end{array}$ & $\begin{array}{l}\text { Tambah, edit, } \\
\text { hapus data } \\
\text { alternatif }\end{array}$ & Sesuai Harapan \\
\hline 9 & $\begin{array}{l}\text { Menginputkan form data } \\
\text { pembayaran santri edit } \\
\text { data, serta hapus data } \\
\text { sesuai dengan keinginan }\end{array}$ & $\begin{array}{l}\text { Tambah, edit, } \\
\text { hapus data } \\
\text { alternatif }\end{array}$ & Sesuai Harapan \\
\hline 10 & $\begin{array}{l}\text { Menginputkan form data } \\
\text { jurnal edit data, serta hapus } \\
\text { data sesuai dengan } \\
\text { keinginan }\end{array}$ & $\begin{array}{l}\text { Tambah, edit, } \\
\text { hapus data } \\
\text { alternatif }\end{array}$ & Sesuai Harapan \\
\hline 11 & $\begin{array}{l}\text { Memilih tombol exit pada } \\
\text { file untuk mengakhiri } \\
\text { program }\end{array}$ & $\begin{array}{l}\text { Mengakhiri } \\
\text { program }\end{array}$ & \\
\hline 12 & $\begin{array}{l}\text { Memilih tombol log out } \\
\text { pada file untuk keluar }\end{array}$ & $\begin{array}{l}\text { Keluar dari } \\
\text { program }\end{array}$ & \\
\hline
\end{tabular}

Pada pengujian sistem didapatkan akurasi tingkat keberhasilan menggunakan beberapa butir uji antara lain, Login, Halaman Utama, Halaman Data Santri, Halaman Data User, Halaman Data Asatidz, Halaman Data Donatur, Halaman Jenis Pembayar, Halaman Transaksi atau Pembayaran, Halaman Jurnal dan Logout. Berdasarkan hasil Black Box tersebut, didapatkan hasil yang sesuai harapan pada butir uji. Sehingga dapat disimpulkan prosentase akurat keberhasilan sistem sebesar $100 \%$.

\section{IV.KESIMPULAN}

Proses pengolahan data keuangan yang berjalan di pondok pesantren Ahmad Dahlan selama ini sudah memanfaatkan penggunaan komputer. Namun belum ada program khusus untuk mengolah data keuangan tersebut, sehingga mengakibatkan timbulnya suatu masalah baru.

Oleh karena itu untuk membantu meningkatkan kinerja administrator di PPTQ Ahmad Dahlan, penulis mencoba memberikan solusi yaitu dengan merancang dan membangun aplikasi Sistem Informasi Akuntansi pada PPTQ Ahmad Dahlan.

Sistem informasi ini bermanfaat untuk memaksimalkan penggunaan teknologi komputer dalam pengolahan data keuangan yang terjadi di PPTQ Ahmad Dahlan. Selain itu sistem ini tidak memerlukan waktu serta tempat yang banyak untuk penyimpanan data.

\section{DAFTAR PUSTAKA}

Alparisi, R., \& Bunyamin. (2015). Pengembangan Sistem Informasi Pengelolaan Data Santri di Pondok Pesantren Ash-Shofi Berbasis Web. Algoritma, 11(1), $1-6$.

Andreas Handojo, Sri Maharasi, Go, O. A. (2004). Pembuatan Sistem Informasi Akuntasi Atas Siklus Pembelian Dan Penjualan. Jurnal Informatika, 5(2), 8694.

Mariani,vini, dkk. (2010). Analisis dan Perancangan Sistem Informasi Akuntansi Penjualan,Piutang dan Penerimaan Kas pada CV.Dekatama, 2010(Snati), 23-28.

Mustakim. (2013). Keuangan Pada Pusat Perusahaan Distributor Air Mineral Mq, 14(04). 